\title{
THE EFFECTS OF TEACHING MEDIA AND GRAMMAR MASTERY TOWARDS STUDENTS' SPEAKING SKILL AT STATE JUNIOR HIGH SCHOOLS IN TANGERANG BANTEN
}

\author{
Fiza Asri Fauziah Habibah \\ Universitas Indraprasta PGRI \\ E-mail: fiza.asri20@gmail.com
}

\begin{abstract}
The research aims to know the effect of teaching media and grammar mastery towards students' speaking skill. This research was conducted at State Junior High Schools Cisauk Tangerang Banten with 574 population and the sample was 60 students which was gained through simple random sampling. This research is a kind of $e x$ periment method which means to give the different treatments upon two students' learning groups. The collection of the data is done by giving multiple choice test. The gain data was then analyzed by using descriptive analysis. The research findings show that there is a significant effect of teaching media towards students' speaking skill at State Junior High Schools Cisauk in Tangerang Banten, there is a significant effect of grammar mastery towards students' speaking skill at State Junior High Schools Cisauk in Tangerang Banten, and there are significant interactive effects of teaching media and grammar mastery towards students' speaking skill at State Junior High Schools Cisauk in Tangerang Banten. Therefore, it can be recommended that the teachers should provide teaching media in teaching speaking skill and the students should have a good grammar mastery to have a good speaking skill.
\end{abstract}

Keywords: Teaching Media, Grammar Mastery, Speaking Skill

\begin{abstract}
ABSTRAK
Penelitian ini bertujuan untuk mengetahui pengaruh media pembelajaran dan penguasaan tata bahasa terhadap kemampuan berbicara siswa. Penelitian ini dilaksanakan di sekolah Sekolah Menengah Pertama di Cisau, Tangerang, Banten dengan jumlah populasi sebanyak 574 orang siswa dan sampel sebanyak 60 orang siswa yang didapat dari teknik random sampling. Penelitian ini menggunakan metode eksperimen yaitu memberikan perlakuan berbeda terhadap dua kelompok siswa. Pengumpulan data dilakukan dengan memberikan tes pilihan ganda. Data yang didapat kemudian dianalisis menggunakan descriptive analysis. Hasil penelitian menunjukkan adanya pengaruh media pembelajaran terhadap kemampuan berbicara siswa di SMPN Cisau, Tangerang, Banten, terdapat pengaruh penguasaan tata bahasa terhadap kemampuan berbicara siswadi SMPN Cisauk, Tangerang, Banten, dan terdapat pengaruh interaktif yang signifikan media pembelajaran dan penguasaan tata bahasa terhadap kemampuan berbicara sisw di SMPN Cisauk, Tangerang, Banten. Oleh karena itu, para guru dianjurkan untuk menyediakan media pembelajaran dalam pengajaran berbicara dan para siswa hendaknya menguasai tata bahasa yang baik agar mempunyai keterampilan berbicara yang baik.
\end{abstract}

Kata Kunci: pengaruh media, penguasaan tata Bahasa, kemampuan berbicara 


\section{INTRODUCTION}

\section{Background}

English is an international language, spoken in many countries both as a native and as a second or foreign language. It is taught in the schools in almost every country on this earth. English is learned everywhere because people have found out that knowledge of English is a passport for better career, better pay, advanced knowledge, and for communication with the entire world. Everyone wants to appropriate English as their own, so it is not surprising that so many people want to learn how to speak English.

The teaching of speaking has great influence to the students' ability. The major problem in the teaching and learning process concerns with inappropriate techniques applied by the teacher. The English teacher tends to teach speaking based on textbook instead of using interesting media. Besides, the lack of media used in English teaching may contribute to the failure of the teaching and learning process; particularly in achieving its goal i.e. students can have good communicative competence. In order to make students interested and motivated, the teacher should provide interesting learning media. Moreover, since the teaching of reading and writing has more portion, students have inadequate opportunities to practice speaking. This fact also leads students to have low speaking skills.

The use of visual media can give students visual clues and provide appropriate models in realistic situations so that students can enjoy the teaching and learning process and understand the materials easily. Considering the need of improving students' speaking skills, the use of visual media as learning media combining with the speaking activities can produce improvement both on quality of the teaching and learning process and the students' speaking skills.

The good communication comes true if persons who are in a conversation or communication understand each other. Other people will understand us if we formulate and arrange the words appropriately. This means that students must master the grammatical structure of English correctly. The mastery of grammatical structures makes them easier to develop the four skills, namely listening, speaking, reading and writing. By mastering the four language skills, students will be able to communicate in English well. It can be assumed that the students' mastery in grammatical structure can be seen from their competency in those four language skills. One of those important skills is speaking.

Grammar is important for a well communication . According to Scacella (1992:141) 'Grammatical competence is an umbrella concept that includes increasing expertise in grammar (morphology, syntax), vocabulary, and mechanics with regard to speaking, the term mechanics refers to basic sounds of letters and syllables, pronunciation of words, intonation, and stress'. This implies that the students should understand English language structures accurately to become fluent. In literature, the resources of the language, including grammar, are used not only for efficient communication of ideas, but also for effective communication . So, we know that if the students want to be a good speaker, they should be mastering of grammar. And Hornby (1994:28) also says that a student who whishes to speak and write English correctly concerned with grammatical correctness. That means grammar and speaking are two significant poles in foreign language learning that it seems, there are nearly related activities. Teaching media has given a big contribution to educational field to improve the teaching and learning process of English, especially speaking. One of various teaching aids or media that 
can be very helpful both for practical or motivational reasons to improve the teaching of speaking is picture.

The use of pictures in the teaching and learning process has important roles to improve the four language skills, especially speaking. Pictures can attract students' attention so that they can be more motivated in learning English. In addition, it can help the teachers transfer the knowledge and materials and make the students understand the materials easily. It also adds variety in the classroom learning so that the students can be more motivated and the teaching and learning process can be more interesting and communicative.

A proper use of grammar is a sign of respect, both for speakers and listeners (Clack, 2010). For speakers, speaking clearly means they take time to polish themselves with a good impression from the listeners. A person with a poor grammar skill can form negative impression on the first time meeting and this may last for a long time. For listeners, a proper use of grammar shows that their thought is concerned. Speakers do not want them to waste time trying to figure out what they are saying.

\section{Formulation of The Problems}

The researcher stated the problems to be researched as follows.

The research questions are:

1. Is there any effect of teaching media towards students' speaking skill at State Junior High Schools Cisauk in Tangerang Banten?

2. Is there any effect of grammar mastery towards students' speaking skill at State Junior High Schools Cisauk in Tangerang Banten?

3. Are there any interactive effects of teaching media and grammar mastery towards students' speaking skill at State Junior High Schools Cisauk in Tangerang, Banten.

\section{Objectives of The Research}

The objectives of this research are to know:

1. The effect of teaching media towards speaking skill at State Junior High Schools Cisauk in Tangerang Banten.

2. The effect of grammar mastery towards speaking skill at State Junior High Schools Cisauk in Tangerang Banten.

3. The interaction effects of teaching media and grammar mastery towards speaking skill at State Junior High Schools Cisauk in Tangerang Banten.

\section{REVIEW OF THE RELATED LITERATURE Speaking Skill}

Speaking is a productive skill. It cannot be separated from listening. Good speaking skill is the act of generating words that can be understood by listeners. A good speaker is clear and informative.

Speaking skill is the skill that give us the ability to communicate effectively. This skill allow the speaker, to convey his message in a passionate, thoughtful, and convincing manner. Speaking skill also help to assure that one won't be miss understood by those who are listening. Thus, speaking skill is the ability to practice regularly what has been learned and trained.

\section{Activities to Promote Speaking}


Kayi (2006) proposes other activities to promote speaking so that students can practice and produce oral language well.

1. Discussion

After a content-based lesson, a discussion can be held for various reasons. The students may aim to arrive at a conclusion, share ideas about an event, or find solutions in their discussion groups. Before the discussion, it is essential that the purpose of the discussion activity is set by the teacher. In this way, the discussion points are relevant to this purpose, so that students do not spend their time chatting with each other about irrelevant things.

2. Role Play

Students pretend they are in various social contexts and have a variety of social roles. In roleplay activities, the teacher gives information to the learners such as who they are and what they think or feel. Thus, the teacher can tell the student that "You are David, you go to the doctor and tell him what happened last night, and." (Harmer, 1984)

\section{Simulations}

Simulations are very similar to role-plays but what makes simulations different than role plays is that they are more elaborate. In simulations, students can bring items to the class to create a realistic environment. For instance, if a student is acting as a singer, she brings a microphone to sing and so on.

\section{Information Gap}

In this activity, students are supposed to be working in pairs. One student will have the information that other partner does not have and the partners will share their information. Information gap activities serve many purposes such as solving a problem or collecting information. Also, each partner plays an important role because the task cannot be completed if the partners do not provide the information the others need.

\section{Brain Storming}

On a given topic, students can produce ideas in a limited time. Depending on the context, either individual or group brainstorming is effective and learners generate ideas quickly and freely. The good characteristic of brainstorming is that the students are not criticized for their ideas so students will be open to sharing new ideas.

5. Storytelling

Students can briefly summarize a tale or story they heard from somebody beforehand, or they may create their own stories to tell their classmates. Story telling fosters creative thinking. It also helps students express ideas in the format of beginning, development, and ending, including the characters and setting a story has to have.

6. Interviews

Students can conduct interviews on selected topics with various people. It is a good idea that the teacher provides a rubric to students so that they know what type of questions they can ask or what path to follow, but students should prepare their own interview questions. After interviews, each student can present his or her study to the class. Moreover, students can interview each other and "introduce" his or her partner to the class.

7. Story Completion

For this activity, a teacher starts to tell a story, but after a few sentences he or she stops narrating. Then, each student starts to narrate from the point where the previous one stopped. 
Each student is supposed to add from four to ten sentences. Students can add new characters, events, descriptions and so on.

\section{Reporting}

Before coming to class, students are asked to read a newspaper or magazine and, in class, they report to their friends what they find as the most interesting news. Students can also talk about whether they have experienced anything worth telling their friends in their daily lives before class.

9. Playing Cards

In this game, students should form groups of four. Each suit will represent a topic. For instance: diamonds represent earning money, hearts represent love and relationships, spades represent an unforgettable memory, and card represent best teacher. Each student in a group will choose a card. Then, each student will write 4-5 questions about that topic to ask the other people in the group. For example: if the topic "diamonds: earning money" is selected, here are some possible questions: Is money important in your life? Why? or .What is the easiest way of earning money? Or What do you think about lottery? Etc. However, the teacher should state at the very beginning of the activity that students are not allowed to prepare yes-no questions, because by saying yes or no students get little practice in spoken language production. Rather, students ask open-ended questions to each other so that they reply in complete sentences.

\section{Picture Narrating}

This activity is based on several sequential pictures. Students are asked to tell the story taking place in the sequential pictures by paying attention to the criteria provided by the teacher as a rubric. Rubrics can include the vocabulary or structures they need to use while narrating.

\section{Picture Describing}

For this activity students can form groups and each group is given a different picture. Students discuss the picture with their groups, and then a spokesperson for each group describes the picture to the whole class. This activity fosters the creativity and imagination of the learners as well as their public speaking skills.

\section{Find the Differences}

For this activity students can work in pairs and each couple is given two different pictures, for example, picture of boys playing football and another picture of girls playing tennis. Students in pairs discuss the similarities and/or differences in the pictures.

From all activities that have mention above, teacher could choose more than one activities to promote speaking activities and avoid monotonous technique. The balance activities in teaching speaking is very important because student could get the balance of input and output.

\section{Teaching Media}

Teaching media is any supporting materials, tools, equipment, or techniques used to facilitate the students' learning and to enable them to acquire the knowledge or understand the contents of the teaching.

Media plays an important and significant role in the English teaching and learning process in establishing students' motivation and enjoyment in learning the language. Generally 
there are three kinds of media. They are visual (e.g. picture), auditory (e.g. songs) and audio visual (e.g. video cassettes).

\section{Effective Media for Teaching Speaking}

Nowadays, advanced technology and teaching media have spread out and have given a big contribution to educational field to improve the teaching and learning process of English, especially speaking. Harmer (2007: 134) proposes the use of various teaching aids or media that can be very helpful both for practical or motivational reasons to improve the teaching of speaking.

\section{1) Pictures and Images}

Pictures and images in the form of flashcards, large wall pictures, cue cards, photographs, and illustrations can be used to facilitate students to learn in a multiplicity of ways such as drilling, understanding, communicative games, and discussions.

\section{2) Realia}

Objects which are intrinsically interesting can provide a good startingpoint to learn a variety of language works and communicative activities. For instance, the teacher sometimes appears in the classroom with two telephones to stimulate phone conversation. Students can also use realia for simulation and role play or to act a script out.

3) Language Laboratory

Language laboratories can provide students a chance of speaking (apart from repetition and drilling) in a number of ways. Students' own talks and speeches can be recorded and then they can listen back and make adjustments. It also can encourage students to practise language which they have recently been focusing.

4) Computer-based Materials

Computer-based materials such as CD, DVD, videos, and movies can give students appropriate models of native speakers' talk and help students to improve their cultural awareness. It also provides real-life context in the classroom.

\section{Picture Teaching Media}

Picture is a two dimensional visual representation of persons, places, or things. Photographic prints are most common, but sketches, cartoons, murals, cutouts, charts, graphs, and maps are widely used. Pictures may be used for individual study, for display on bulletin boards and feltboards, in exhibits, and for projection when groups of students need to look at one picture at the same time.

Pictures may be drawn, printed, or photographically processed. They vary in size and color. They may be highly representational or abstract. If a picture is desirable for classroom use and it is in a book or pamphlet which is available to an entire class, it probably would be most efficient to ask everyone to turn the same page at the same time to look at the picture. If, however, only one copy of a picture is available and group viewing is required, the picture could be projected on a screen.

A picture can be mounted for preservation. If the image is in a magazine, you may be able to cut out the page and mount it to a rigid backing. If it is in a book or magazine which you do not wish to damage, you can use a reproduction process that will inexpensively photocopy either black and white or color images. Either an original or a legitimate copy can be mounted on a backing surface and displayed or circulated among your pupils. You can pro- 
tect a mounted picture by laminating it. By using either a heat-sensitive or pressure-sensitive laminating film, you can put a permanent, transparent cover over your material. In addition, you or your students can write directly on the laminated surface with either a grease pencil or water-soluble pen and erase this writing by wiping with a damp cloth. Lamination is especially useful for independent study materials that are handled by students.

\section{The Advantages of Using Picture}

There are some roles and advantages of pictures in speaking as mentioned by Wright (1989:17).

1. Pictures can motivate the student and make him or her want to pay attention and want to take part.

2. Pictures contribute to the context in which the language is being used. They bring the world into the classroom.

3. The pictures can be described in an objective way.

4. Pictures can cue responses to questions or cue substitutions through controlled practice.

5. Pictures can stimulate and provide information to be referred to in conversation, discussion and story telling.

\section{Picture Teaching Technique}

Pictures can be used by teachers and students whatever the emphasis of the syllabus they are following. Here are some ideas for using opaque still pictures:

1. Have students gather magazines, from home, clubs, or school, from which pictures can be removed. Have a class project of building a picture file or tear sheet collection. Determine a system for cataloging the visual materials by first selecting some very general categories, that is, people pictures, animal pictures, foreign country pictures, etc. (for elementary grades) or pollution pictures, political figures, science/technology pictures, etc. (for upper grades). Have students remove visuals from the magazines and file them under the appropriate headings. As you acquire more tear sheets, you may want to refine the categories. This exercise will aid instruction in several ways: (a) it will give students experience with filing and matching, (b) students will exercise skills in visual literacy, (c) it will provide a resource for the preparation of visual presentations, and (d) students will have a resource for visualizing reports, term papers, and classroom presentations.

2. Have students arrange a set of pictures in such a way that the tell a story. This will test the students ability to organize and to communicate.

3. Show an unusual picture to students perhaps an object or place that they have never seen before. Use the discovery or directed discussion technique to encourage them to describe what they are looking at. Play a visual questions game by dividing the class into two groups; the group that correctly describes the object or place earns a point.

4. For creative writing or decoding visual information show a picture or study print that has much visual information and have student write or tell a story which describes the relationship of the people in the picture and the way he environment in the picture was created. 
5. For explaining a sequential process, take photos of the specific steps (for example, how to load film into a camera). Explain the process to the class, using the photos; then rearrange the order and have a student place the photos in the correct sequence.

6. You can create many valuable teaching pictures with your own camera. If you are going to visit a place of interest, take your camera with you and create some pictures for instructional use.

7. Let your students create photo stories if their own. A simple camera will suffice; it is easy and inexpensive to use

8. Make a student of the week or month display in your classroom. Take a picture of the students who have done outstanding work during this period of time and put the photo in a frame above a display of their outstanding project

9. Whenever something unusually exciting happens for your class a guest speaker, United Nations Day, or a holiday take a picture of it and make a special events bulletin board display to be added to after each event. You may also use the pictures during a parents visiting night.

10. Record your students physical and emotional growth. Take a photo of each of our students at the beginning of the year; take one at the end of the year, too. Let students compare the before and after photos; use this as a stimulus to have them explain how they grew during their year in your class. This could also be carried on between grade levels. Such pictures also provide identification of former pupils.

11. Create a photo montage poster on a topic of study. A photo montage is created by combining still pictures from varying sources in such a way that these separate visual elements blend together

12. Compare an aerial photo of a local area with a map of the area. This activity can make map reading more interesting and can also become a lesson on perspective. Aerial photos can be secured from the local weather bureau, a pilots association or department of public safety

13. Place several pictures on the bulletin board, but cover them with pieces of construction paper that are cut so that only a small part of each picture can be seen. Have students write about what they think the whole picture is. Encourage the active use of imagination, stressing that an exact description of the picture does not necessarily constitute the "right answer"

\section{Grammar Mastery}

According to Rutheford (1987), grammar is "a necessary of any language teaching program", and thus plays an important role in language . however focus on grammar in language teaching was challenged with the emergence of teaching methodologies based on different learning theories, such a challenge influenced not only the content and the curriculum in language teaching, but also the implication for teaching grammar. While according to Hornby (1987), mastery is complete control or knowledge.

As an important element of language, grammar should be mastered by learners if they want to be successful in learning English. Mastering English grammar can help students to construct the correct sentences meaningfully and grammatically, so that they are able to use 
English well. Improving grammar mastery is crucial for the students because if grammar rules are too carelessly violated, communication may suffer (Harmer, 2001).

\section{Teaching Techniques for Supporting Grammar Learning}

Some techniques can be used to improve the grammar mastery for the students. They are:

1. Working from discourse to grammar

Many types of discourse that occur in young learner classrooms have grammatical patterns that occur naturally, but that can be exploited for grammar learning. It requires teachers to think about their language use from a grammatical perspective, so that they become aware of opportunities for grammar that arise every day.

\section{The language of classroom management}

When children begin learning English, some very simple phrases for classroom management can be introduced, and as time goes by, these can be expanded. Some of the phrases originally used by the teacher can be used by pupils when they work in pairs or groups.

\section{Talking with children}

As with the T Rex example where we started, conversations with individual children can be very powerful for language development, because they can pick up on exactly what an individual child needs to know next to talk about what interests him or her.

2. Guided noticing activities

Activities in the previous section are those likely to lead to noticing of grammatical patterns in the language. It is possible to construct activities that make noticing even more probable, and which fit all or most of the criteria for good noticing activities.

\section{Listen and notice}

Pupils listen to sentences or to a connected piece of talk, e.g, a story or phone call, and complete a table or grid using what they hear.

\section{Presentation of new language with puppets}

In language syllabuses that require teachers to present new language regularly to children, the idea of learner-noticing can be helpfully introduced into more traditional ways of teaching grammar.

\section{Questionnaires, surveys and quizzes}

These are commonly found in young learner course books; after input on favourite foods, for example, children are asked to interview their friends to find out their favourite foods. The teacher needs to plan which language forms the pupils will be encouraged to use.

\section{Information gap activities}

Activities with information gaps are often found in course books to practice oral skills. Again, with just small adjustments, they can be used with grammar goals rather than oral fluency goals.

\section{Helping hands}


This is a nice practice activity that I came across in a maltese classroom, and which offers opportunities for structuring the simple present for routines.

\section{Drills and chants}

Drills have been used in language classrooms for decades, and are a useful way of giving all children some speaking practice when the class is too large for individual speaking. They also offer language and involvement support to children when used to practice new language, because the child can listen to others to pick up bits that she or he is unsure about, and drills can be lively and fun if the pace is kept up.

3. Proceduralising activities

At this point, we want learners to automatise their use of the grammatical form so that it is available quickly and effectively for use in communication. Task design must ensure that grammar is essential for achieving task goals and that some attention to accuracy is required, but the idea is that attention to accuracy can gradually be relaxed as it becomes automatic.

\section{Polar animal description re-visited}

It will be helpful to recall what happened to the polar animal description. We looked at speaking activities on this theme, but here we can think about the task possibilities from a grammatical point of view.

\section{Dictogloss}

This is a generic activity that offers many possibilities for young learner classrooms (as well as for older and adult learners) once reading and writing are established. Wajnryb (1990) describes various activities that pick up some of the learning opportunities of traditional dictation in more meaningful ways.

\section{Hypothesis}

Based on theoretical description and framework of Thinking, the research hypothesis can be formulated as follows:

1. There is a significant effect of teaching media towards students' speaking skill.

2. There is a significant effect of grammar mastery towards students' speaking skill.

3. There are significant interactive effects of teaching media and grammar mastery towards students speaking skill.

\section{RESEARCH METHODOLOGY \\ Place of Research}

This research was conducted at State Junior High Schools Cisauk Tangerang Banten. These schools are chosen to become the places of research due to schools' achievements, and facilities. These schools are designed not only for academic purpose but also for leadership matter. Thus, their students are hopefully being intellectuals who are able to become the leader.

\section{Time of Research}

The time allotment for this research was set in the forth semester of academic year 2017--2018, precisely from August to December 2017.

\section{Research Method}


This research used experiment method, which means to give the different treatments upon two students' learning groups. One group is treated as experiment group, which is given treatment by using picture media, while another group is given treatment by using conventional one. For each group, then it will be divided into two, a group of student with high grammar mastery, and a group of student with low grammar mastery.

\section{Research Population}

The research population of this research is all students of State Junior High Schools Cisauk Tangerang Banten, seventh grade which possesses 574 students which is divided into 14 parallel classes, where each class consists of more or less 40 students.

\section{Sample}

In this research, total sample is 60 students, who are divided into 2 classes; one experiment class consists of 30 students, and one control class consists of 30 students as well. The experiment classes are VII-A and VII-B class, while the control classes are VII -C and VII -D class. The classes are located at the different school ( 2 schools). In this research, there are 4 groups with different treatment and different ability.

\section{Research Instrument}

\section{1. $\quad$ Speaking Skill}

In assessing the speaking skill, Underhill (2004: 96) stated that there are five skill aspects should be measured: fluency, grammar, pronunciation, vocabulary, and comprehension. Thus, in measuring the speaking skill, the range of skill is set in the following 5 (outstanding), 4 (excellent), 3 (good), 2 (fair), and 1 (need improvement).

\section{Grammar Mastery}

The students' grammar mastery scores obtained by multiple-choice test. The multiple choice item is the most versatile type of test item available. It can be measure a variety of learning outcomes from simple to complex, and it is adaptable to most type of subject-matter content. It has such wide applicability and so many uses that many standardized tests use multiplechoice items exclusively. There are 25 numbers of grammar mastery test which every single one correct number will be given one score.

\section{Descriptive Analysis}

Descriptive analysis is done by data presentation techniques in the form of frequency distribution table, graphs / bar charts for each variable. In addition, each variable will be processed and analyzed the size of concentration and location such as mean, mode, and median and the size of deviation such as range, variance, standard deviation, skewness and kurtosis.

\section{RESEARCH FINDINGS AND DISCUSSIONS Research Findings \\ Data Description}

1. Data description of students' speaking skill with picture media

The data of students' speaking skill with picture media obtained from the test score of respondents who became the sample of research as many as 30 students. The value obtained is the lowest score 65 , the highest score 95 , the average score of 82.00 , the median of 80 , the mode of 80 and standard deviation of 9,248. 
From the results of the above calculation, it can be said that the students' speaking skill with picture media at State Junior High Schools Cisauk in Tangerang Banten is high. This is indicated by an average score of 82.00 .

2. Data description of students' speaking skill with conventional media

The data of students' speaking skill with conventional media is obtained from the test score of respondents who become the research sample of 30 students. The lowest score is 65 , the highest score 95 , the average score is 77.33 , the median is 75 , the mode is 70 and the standard deviation is 7,849 .

From the above calculation, it can be said that the students' speaking skill with conventional media at State Junior High schools Cisauk in Tangerang Banten quite enough. This is indicated by an average score of 77.33 .

3. Data description of students' speaking skill with high grammar mastery

Data of students' speaking skill who possess a high grammar mastery, obtained from the test score of respondents who become the research sample of 30 students. The lowest score is 65 , the highest score is 95 , the average score is 83.17 , the median is 85 , the mode is 95 and the standard deviation is 9,513 .

From the results of the above calculation, it can be said that the students' sepaking skill with high grammar mastery at State Junior High Schools Cisauk in Tangerang Banten is high. This is indicated by an average score of 83.17.

4. Data description of students' speaking skill with low grammar mastery

Data of students' speaking skill who possess low grammar mastery is obtained from the value of the respondent test into a sample of 30 students. The scores obtained are the lowest score 65 , the highest score 95 , the average score of 75.17 , the median of 75 , the mode of 70 and the standard deviation of 6.757 .

From the results of the above calculation, it can be said that the students' speaking skill who possess low grammar mastery at State Junior High Schools Cisauk in Tangerang Banten quite enough. This is indicated by an average score of 75.17.

\section{Test of Data Analysis Requirements Normality Test}

Normality test on the dependent variable and / or kovariate variable in need. Especially to determine whether the next analysis approach uses parametric or non parametric statistics. If the data follow a test of normality or other theory of distribution tests, then the analysis can be continued with parametric statistics.

The value of statistical test Kolmogorov-Smimov $\mathrm{Z}=1.005$ and the value of Sig. $<0.05$. This means that all of the above data is normally distributed.

\section{Homogeneity Test}

In addition to the normality test, one of the necessary requirements in analyzing data using ANOVA is the homogeneity test of the variant. While the purpose of homogeneity test is to find out whether the population variance by group designed, is homogeneous or not. Homogeneity test on learning media data was done by Levene's test at 5\% significance level.

It is obtained data $\mathrm{Fh}=0.240$ and Sig. $=0.868>0.05$. It means that the data comes from a homogeneous sample. Thus the null hypothesis is accepted. This means the sample comes from a population that has the same variance (homogeneous). This normality and ho- 
mogeneity test above can be concluded that the requirements to be met by the research data to be processed with ANOVA techniques have been met.

\section{Hypothesis Testing}

\section{Hypothesis Testing Research}

\begin{tabular}{|c|c|c|c|c|c|}
\hline & Tests of Be & Neen-s & ubjects Effec & & \\
\hline Dependent & iable: Student & s Engl & sh Speaking S & Skill & \\
\hline Source & $\begin{array}{l}\text { Type III } \\
\text { Sum of } \\
\text { Squares }\end{array}$ & Df & $\begin{array}{c}\text { Mean } \\
\text { Square }\end{array}$ & $\mathrm{F}$ & Sig. \\
\hline $\begin{array}{l}\text { Corrected } \\
\text { Model }\end{array}$ & $2028.333^{\mathrm{a}}$ & 3 & 676.111 & 13.869 & .000 \\
\hline Intercept & 376041.667 & 1 & 376041.667 & 7713.675 & .000 \\
\hline $\mathrm{A}$ & 481.667 & 1 & 481.667 & 9.880 & .003 \\
\hline $\mathrm{B}$ & 1306.667 & 1 & 1306.667 & 26.803 & .000 \\
\hline$A * B$ & 240.000 & 1 & 240.000 & 4.923 & .031 \\
\hline Error & 2730.000 & 56 & 48.750 & & \\
\hline Total & 380800.000 & 60 & & & \\
\hline \begin{tabular}{|l} 
Corrected \\
Total
\end{tabular} & 4758.333 & 59 & & & \\
\hline R Squ & 6 (Adjus & $\mathrm{R} \mathrm{S}$ & $\mathrm{red}=.396)$ & & \\
\hline
\end{tabular}

Based on the above data, the proposed research hypothesis can be answered. The explanation of the above table is as follows:

1. First Hypothesis: there is a significant effect of teaching media towards students' speaking skill at State Junior High Schools Cisauk in Tangerang Banten.

Based on the Table, it is obtained Sig value. $=0.003<0,05$ and $\mathrm{Fh}=9,880$, then the null hypothesis (Ho) is rejected and the alternative hypothesis (H1) is accepted. This means that there is a significant effect of teaching media towards students' speaking skill at State Junior High Schools Cisauk in Tangerang Banten. Or in other words, there is a difference of speaking skill among students who use the picture media with those who use conventional media.

2. Second Hypothesis: There is a significant effect of grammar mastery towards students' speaking skill at State Junior High Schools Cisauk in Tangerang Banten. 
Based on the table, it is obtained Sig value. $=0,000<0,05$ and $F h=26,803$, then the null hypothesis (Ho) is rejected and the alternative hypothesis (H1) is accepted. This means that there is a significant effect of grammar mastery towards students' speaking skill at State Junior High Schools Cisauk in Tangerang Banten. Or in other words, there is a difference of English speaking skill among students who possess high grammar mastery with those who possess low grammar mastery.

3. Third Hypothesis: there are significant interactive effects of teaching media and grammar mastery towards students' speaking skill at State Junior High Schools Cisauk in Tangerang Banten.

Based on the Table, it is obtained Sig value. $=0.031<0.05$ and $\mathrm{Fh}=4.923$, then the null hypothesis (Ho) is rejected and the alternative hypothesis (H1) is accepted. This means that there are non significant interactive effects of teaching media and grammar mastery towards students' speaking skill at State Junior High Schools Cisauk in Tangerang Banten.

Meanwhile, the value of Adjusted R. Squared of 0.396 means that the teaching media and the grammar mastery give $39.6 \%$ effects on the improvement of students' speaking skill at State Junior High Schools Cisauk in Tangerang Banten.

\section{Discussion}

1. There is a significant effect of teaching media towards students' speaking skill at State Junior High Schools Cisauk in Tangerang Banten.

Based on the findings of the research, it is stated that the use of teaching media has significant effect towards students' speaking skill at State Junior High Schools Cisauk in Tangerang Banten. Or in other words, there is a difference of students' speaking skill who use the picture media with those who use conventional media. This can be seen from the average score of students' English speaking skill using picture media is 82, while the average score of English speaking skill of students using conventional media is 77.33.

2. There is a significant effect of grammar mastery towards students' speaking skill at State Junior High Schools Cisauk in Tangerang Banten.

Based on the findings of the research, grammar mastery has a significant effect towards students' speaking skill at State Junior High Schools Cisauk in Tangerang Banten. In other words, the students' speaking skill who possess high grammar mastery is higher than the students' speaking skill who possess low grammar mastery. This can be seen from the average score of English proficiency ability of students who possess a high grammar mastery is 83.17, while the average score of the students' speaking skill who possess low grammar mastery is 75.17 .

3. There are significant interactive effect of teaching media and grammar mastery towards students' speaking skill at State Junior High Schools Cisauk in Tangerang Banten.

From the findings of the research, it can be stated that teaching media and grammar mastery has significant interactive effects towards students' speaking skill at State Junior High Schools Cisauk in Tangerang Banten.

\section{CONCLUSIONS AND SUGGESTIONS} Conclusions 
According to the result of hypothesis test in chapter IV, it can be concluded that:

1. There is a significant effect of teaching media towards students' speaking skill at State Junior High Schools Cisauk in Tangerang Banten. It is proved by the value of Sig. $=0,003<$ 0,05 and $\mathrm{Fh}=9,880$.

2. There is a significant effect of grammar mastery towards students' speaking skill at State Junior High Schools Cisauk in Tangerang Banten. It is proved by the value of Sig.= $0,000<0,05$ and $\mathrm{Fh}=26,803$.

3. There are significant interactive effects of teaching media and grammar mastery towards students' speaking skill at State Junior High Schools Cisauk in Tangerang Ban ten. It is proved by the value of Sig. $=0.031<0.05$ and $\mathrm{Fh}=4.923$.

\section{Suggestions}

1. In an effort to improve the students speaking skill, teacher should pay attention to the existence of teaching media and grammar mastery, by making improvement not only in learning performance but also in speaking skill practice by considering several indicators that closely related to speaking skill, such as various teaching media and grammar mastery. Moreover it is an obligatory for the English teachers to provide the speaking class for their students so that the students communicating skill will be improved, as the proverb says: practice makes perfect

2. Teacher should pay attention to the existence of teaching media and grammar mastery in English lesson. This helps the acceleration in learning process so that students can gain success for their speaking skills. Therefore the teaching media and grammar mastery should be up optimized simultaneously; hence the responsive learning activity could be implemented 3. To improve students speaking skill is highly depends on the motivation of teachers in maximizing the teaching media and grammar mastery in process of learning. Teachers should be able to control and restrain the students in a school environment with their authority, especially in the classroom

4. Teacher should improve students' grammar mastery to be better, besides encouraging them to be able to please the subjects taught, so that the students preferences of grammar mastery in learning process could be pump up their achievement

5. The research is still very brief $n$ detail. Hence the writer suggests that it is needed to conduct further research to find the effects of teaching media and grammar mastery towards students speaking skill. 


\section{REFERENCES}

Arikunto, S. 1985. Prosedur Penelitian. Jakarta: Rineka Cipta.

Beatty, F. L. 1981. The Instructional Media Library. Still Picture. Number 14. New Jersey: Educational Technology Publications.

Brown, H.D. 2001. Teaching byPprinciples: An Interactive Approach to Language Pedagogy .2nd Edition. New York: Addison Wesley Longman, Inc.

Brown, H.D. 2004. Language Assessment: Principles and Classroom Practices. Essex: Pearson Education, Inc.

Cameron, L. 2001. Teaching Language to Young Learners. Cambridge: Cambridge University Press.

Gerlach, Ely, \& Melnick. 1980 . Teaching and Media: A Systematic Approach. Second Edition. United States of America: Prentice_ Hall, Inc.

Linn, Robert L. Gronlund, \& Norman E. 1990. Measurement and Assessment in Teaching. Garamond: Carlisle Communications, Ltd.

Mutakin, T.Z. \& Cleopatra, Maria. 2015. Suplemen Aplikasi Komputer dalam Penyusunan Karya Ilmiah. Tangerang: Pustaka Mandiri.

Sugiyono. 2007. Metode Penelitian Pendidikan: Pendekatan Kuantitatif, Kualitatif, dan $R \& D$. Bandung: Alfabeta.

Thornburry, S. 1999 . How to TeachGgrammar. Edinburgh Gate: Pearson Education Limited.

Thornbury, S. 2005. How to TeachSspeaking. London: Longman.

Wright, A. 1989 . Pictures for Language Learning. United Kingdom: Cambridge University Press. 